\title{
Antipsychotics for the Treatment of Behavioral and Psychological Symptoms of Dementia (BPSD)
}

\author{
Rosa Liperoti ${ }^{1}$, Claudio Pedone ${ }^{2}$ and Andrea Corsonello, $3,4, *$ \\ ${ }^{1}$ Centro di Medicina dell'Invecchiamento, Dipartimento di Scienze Gerontologiche, Geriatriche e Fisiatriche, Università \\ Cattolica del Sacro Cuore, Largo A. Gemelli, I-00168 Rome, Italy; ${ }^{2}$ Area di Geriatria, Università Campus BioMedico, \\ Via dei Compositori, I-00100 Rome, Italy; ${ }^{3}$ Fondazione San Raffaele, Cittadella della Carità, I-74100 Taranto, Italy; \\ ${ }^{4}$ Istituto Nazionale di Ricovero e Cura per Anziani (INRCA), I-87100 Cosenza, Italy
}

\begin{abstract}
Behavioral and psychological symptoms of dementia (BPSD), i.e. verbal and physical aggression, agitation, psychotic symptoms (hallucinations and delusions), sleep disturbances, oppositional behavior, and wandering, are a common and potentially severe problem complicating dementia. Their prevalence is very high and it is estimated that up to $90 \%$ of patients with Alzheimer's disease (AD) may present at least one BPSD. Beside the obvious impact on the quality of life of people with dementia, BPSD are responsible for increased risk of patient institutionalization and increased costs. Furthermore, they are associated with caregivers' stress and depression. Drugs used include antipsychotics, antidepressants, anticonvulsivants, anxiolytics, cholinesterase inhibitors and N-methyl-D-aspartate receptor modulators. Among these, the most commonly used are anti-psychotics. These drugs have been used for many decades, but in the last years new compounds have been marketed with the promise of comparable efficacy but less frequent adverse effects (especially extra-pyramidal side effects). Their safety, however, has been challenged by data showing a potential increase in adverse cerebrovascular side effects and mortality. This review will summarize the pathophysiology and neuropharmacology of BPSD, it will describe the characteristics of the anti-psychotics most commonly used focusing on their efficacy and safety in BPSD.
\end{abstract}

Key Words: Behavioral and psychological symptoms of dementia (BPSD), dementia, antipsychotics.

\section{INTRODUCTION}

Dementia is one of the most important problems in clinical practice given the growth of elderly populations in the last decades [33]. While the hallmark of all dementia syndromes is the decline of varying cognitive abilities, cognitive impairment should not be considered the only important symptomatology present in dementia. The term "behavioural and psychological symptoms of dementia" (BPSD) describes a wide spectrum of non-cognitive manifestations of dementia, including verbal and physical aggression, agitation, psychotic symptoms (hallucinations and delusions), sleep disturbances, oppositional behavior, and wandering [7, 18].

BPSD are very frequent in dementia: up to $90 \%$ of patients with Alzheimer's disease (AD) may present at least one of these symptoms, and it can be estimated that about one-third of AD patients have severe problems [10, 16, 45, 61, 62]. Agitation, aggressiveness, wandering, oppositional behaviour and psychotic disorders are present in about 10$50 \%$ of patients with $\mathrm{AD}$, with a considerable impact on the functional status $[8,9,14,25,26,45,54]$. Indeed, these symptoms are very invasive and difficult to manage by the caregivers and the care teams $[14,16,61]$.

BPSD may not be obvious during the early stages of AD, but these symptoms are also present in dementia syndromes other than AD, such as dementia with Lewy bodies or frontotemporal lobar degeneration $[63,68]$, where they may appear also in the early stages. Thus, the course of BPSD differ according to the type of dementia $[11,20,55]$. Finally, the ap-

\footnotetext{
*Address correspondence to this author at Via della Resistenza Pal. Alfa Scala H, I-87036 Rende (CS), Italy; Tel: +39 09844618 72; Fax: +39 0984 4618 72; E-mail: andrea corsonello@tin.it
}

pearance of psychotic symptoms is a relevant risk factor for the development of aggressive behaviour and agitation, and is associated with a poorer functional prognosis [20,54].

Anyway, the appearance of BPSD during the evolution of any dementia syndrome represents a major management problem for both physicians and caregivers, and the evolution of these symptoms is the major reason for caregiver "burnout" and patient institutionalization, with an enormous increase in medical and indirect costs, and with a frequent decrease in quality of life for the patient and the caregiver [7, $17,33]$.

The etiology of these symptoms is yet to be definitely clarified, and this certainly contributes to limit the pharmacological approach to BPSD. Nonetheless, it is conceivable that several factors including neurobiological, physical and environmental components are likely to be involved [7]. We will focus on the pathophysiological mechanisms underlying BPSD and the neuropharmacology of drugs used for the treatment of these symptoms, and we will also discuss the available evidence regarding the efficacy and the safety of conventional and atypical antipsychotics in patients with BPSD.

\section{PATHOPHYSIOLOGY OF BPSD}

There is convincing evidence that the origin of BPSD in $\mathrm{AD}$ derives from identifiable anatomical and biochemical abnormalities. Given the wide array of psychopathologic symptoms in $\mathrm{AD}$, however, it is unlikely that lesions of specific brain structure is related with a specific BPSD. Furthermore, it is likely that baseline psychological factors are involved along with biological factors in the appearance of behavioural problems [65], although a retrospective bias can be in part responsible for the observed associations [79]. 
Genetic studies show that chromosomal abnormalities are a risk factor for the development of BPSD. For example, a relationship between presenilin 1 and psychosis has been demostrated [39]. An association has also been shown between polymorphism of serotonin receptors genes $\left(5 \mathrm{HT}_{2 \mathrm{~A}}\right.$ $102-\mathrm{T} / \mathrm{C}$ and $5 \mathrm{HT}_{2 \mathrm{C}} \mathrm{Cys} 23 \mathrm{Ser}$ ) and visual and auditory hallucinations, with the two polymorphisms having an additive effect on visual hallucinations [44]. Polymorphism of the dopamine receptors genes is also involved: in 275 outpatients with probable AD, homozygous for DRD1 allele B1 and homozygous for either DRD3 allele were both associated with psychosis [83].

A genetic polymorphism of the serotonin transporter promoter region (L/L genotype) has been implicated with aggressive behaviour in patients with $\mathrm{AD}$ [81]. The same genotype seems to be associate with a distinctive phenotype characterized by psychotic symptoms and aggressive behaviour [84].

The typical pathologic lesions of $\mathrm{AD}$, neurofibrillary tangles (NFT), exhibit a characteristic distribution pattern that is correlated with dementia stage. In the earlier stages, there is an invasion from the enthorinal cortex to the hippocampus, while in more advanced stages there also is an involvement of the neo-cortex [12]. While "negative" psychiatric symptoms (such as depression) can be evident even before a diagnosis of AD is made, "positive" symptoms (agitation, aggressive behaviour) appear usually at later stages of dementia, after the appearance of cognitive abnormalities and presumably when the neo-cortex is invaded by NFT [47].

As can be expected, different behavioural problems reflect involvement of different cerebral areas. It has been shown that people with $\mathrm{AD}$ who develop psychosis have a 2.3 -fold greater density of NFT in the neo-cortex (middle frontal, anterior third of the superior temporal, inferior parietal) compared to AD patients who will not develop psychosis [29]. Neurofunctional imaging studies have shown that psychosis in probable AD is associated with a reduction in prefrontal, left frontal-temporal, and right parietal metabolism $[61,82]$. These evidences, however, come from studies with very small sample size.

Delusional misidentification (such as the belief that a close relative has been replaced by some other person having the same appearance) have been found to be correlated with lower neurone count in the CA1 area of the hippocampus; in the same study a lower neurone count in the dorsal raphe was associated with delusions and hallucinations [34].

Higher NFT concentration has been reported in the orbito-frontal cortex of $\mathrm{AD}$ patients with agitation [85], while single-photon emission CT demonstrated hypoperfusion of the left anterior temporal cortex in AD patients showing aggressive behaviour [43]. Also in non-AD dementia, there seems to be an association between location of pathologic lesions and behavioural problems. In Lewy's disease, for instance, it has been shown that there is a strong association between the density of Lewy's bodies in the amygdala and parahyppocampal cortex and the presence of severe visual hallucination [38].

\section{PHARMACOLOGY OF ANTIPSYCHOTICS}

As different cerebral regions are involved in the pathogenesis of BPSD, different neurotransmitters have been found to be implicated in these disturbances (acetylcholine, dopamine, serotonine). Most pharmacologic treatment for BPSD are based else on drugs increasing the activity of these neurotransmitters (acetylcholine), or by decreasing or modulating it (dopamine, serotonine).

For decades, the mainstay of treatment for psychosis in dementia have been the so-called "conventional" or firstgeneration antipsychotics, that have been used since the " $50 \mathrm{~s}$. There are three principal chemical classes of these drugs (phenotiazines, butyrophenones and thioxanthenes), and all of them share high affinity for the D2 dopamine receptor. The efficacy of these drugs is strictly correlated with the occupancy rate of D2 receptors: a PET study demonstrated that D2 occupancy predicted the clinical response to haloperidol, and that a threshold of $65 \%$ occupancy rate provided a good separation between responders and non-responders [50]. These results are consistent with others obtained with a different antipsychotic drug (raclopride) [70]. The occupancy of D2 receptors in the basal ganglia is also correlated with extra-pyramidal effects of these drugs $[30,70]$, as well as to other side effects such as hyperprolactinemia [50]. Firstgeneration anti-psychotics have been also shown to block D2 receptors in the limbic cortical areas, and this activity seems to be most important in treating psychotic symptoms [89].

Newer anti-psychotic drugs have been dubbed "atypical" because they seem to induce extra-pyramidal effects less frequently and because they seem to have therapeutic efficacy in patients who do not respond to first-generation antipsychotics.

Clozapine is the prototype of this newer anti-psychotic agents. Its pharmacodynamic profile includes low affinity for both D1 and D2 dopamine receptors, along with high affinity for D4 dopamine receptor and serotonine receptors (5HT2 and 3) [51]. It also has an anti-glutamatergic action [56], as well as alpha-2 receptor affinity and M1 cholinergic receptor blocking activity [28]. Dopamine receptors block by clozapine is evident especially in the mesolimbic, but not in the nigro-striatal system [3], and this can in part account for the low incidence of extrapyramidal side effects.

Enhanced efficacy and reduced extra-pyramidal symptoms observed with second-generation anti-psychotic drugs have been explained with their high 5HT2/D2 activity [67]. More recently, the fast dissociation of "atypical" antipsychotics from the D2 receptor compared to older drugs has been proposed as the mechanism by which these drug have an anti-psychotic effect without extra-pyramidal effects or prolactine elevation [49]. Despite its seemingly optimal pharmacological profile, use of clozapine is not widespread because a consistent risk of agranulocytosis.

Risperidone has been marketed as an atypical antipsychotic because of its 5HT2/D2 affinity ratio. However, it has been shown a similar proportion of $\mathrm{D} 2$ receptors occupied by risperidone and haloperidol [48]. Olanzapine was introduced shortly after risperidone, and has a pharmacologic profile similar to clozapine [28]. Quetiapine was the fourth "atypi- 
cal" anti-psychotic marketed, it has a chemical structure and multi-receptor activity similar to clozapine [72], and acts selectively in the limbic system [46]. Ziprasidone, although structurally different from other antipsychotics, also shows a high 5HT/D2 ratio, although its affinity for D2 receptors is high [32].

Benzamides (sulpiride and amisulpiride) are highly selective antagonistis of dopamine at the D2 and D3 receptors with a preferential limbic activity. Besides this post-synaptic actions, it has been shown to antagonize the pre-synaptic receptors that modulate dopamine release [77].

Aripiprazole is a newer antipsychotic agent with a mechanism of action that is different from both first and second generation antipsychotics. It acts as a partial agonist at the D2 and 5HT1A receptors and as an antagonist at the 5HT2A receptor, and is considered a "stabilizer" of the dopamine/serotonin system [15].

\section{EFFICACY OF ANTIPSYCHOTICS}

Conventional antipsychotics have been approved in the 1950s mainly for the treatment of schizophrenia. Since then, these agents have been systematically used for the treatment of BPSD in spite of a substantial lack of scientific evidence supporting their use in dementia. Few trials investigating the efficacy of conventional agents for the treatment of BPSD have been conducted between the 1960s and the late 1980s $[6,60,75]$. These studies mainly focused on the effect of haloperidol and thioridazine. They were characterized by small sample sizes and possible lack of power. Data from these early studies showed a modest advantage of conventional antipsychotics over placebo with a nearly $40 \%$ placebo response, and only $18 \%$ benefit over placebo in the metaanalysis by Schneider et al. [75]. Also, according to some of these studies, the observed superiority of conventional antipsychotics over placebo would be limited to symptoms of aggression and it would be absent in other behavioural and psychotic symptoms [60].

Atypical antipsychotics have been licensed in the 1990s and approved by The US Food and Drug Administration (FDA) exclusively for the treatment of schizophrenia. Rapidly after their introduction in clinical practice, these medications have become the new standard of care for BPSD due to their reported advantages over conventional agents, particularly with respect to extrapyramidal symptoms (EPS) and tardive diskinesia $[19,35,68]$. Over the last decade, the offlabel use of atypical antipsychotics in dementia has been promoted by clinical practice guidelines although the limited number of clinical trials suggesting the efficacy of these agents in dementia [2, 37]. In the late 1990s, atypical agents accounted for more than $80 \%$ of antipsychotic prescriptions in dementia [37, 59]. To date 22 randomized placebocontrolled trials have investigated the efficacy of atypical antipsychotics for the treatment of BPSD. Only eleven of these studies have been published in full at the time of completion of this review (Table 1). No data from double blind randomized clinical trials on patients with dementia are available for amisulpride, clozapine, sertindole, ziprasidone or zotepine.

Compared to placebo, risperidone has been shown to be beneficial on psychotic symptoms and aggression at doses of
$1 \mathrm{mg}$ and $2 \mathrm{mg}$ per day in three placebo controlled clinical trials $[13,23,52]$. These studies were conducted on patients with Alzheimer's disease, vascular dementia or mixed dementia on a 12 weeks time-period.

Olanzapine has been shown significantly effective for improving behavioural symptoms, psychosis and aggression at 5 to $10 \mathrm{mg}$ per day dose compared with placebo $[22,80]$. This evidence derives from two randomized placebocontrolled clinical trials conducted among patients with dementia for a 10 week and 6 week period of time respectively $[22,80]$. In contrast with these data, a recent study on patients with moderate to severe psychotic symptoms of dementia randomly assigned to receive a flexible dose of olanzapine (2.5-10.g per day), risperidone (0.5-2 mg per day) or placebo demonstrated similar improvement of BPSD in the three treatment groups with higher discontinuation rate due to adverse events in the olanzapine and risperidone groups [24].

Very recently, a 10-week, double- blind, placebo controlled study has shown that quetiapine at a fixed dose of 200 $\mathrm{mg}$ per day is effective and well tolerated for treating agitation in institutionalized patients with dementia [90]. Also, one published study involving a small number of patients with dementia has demonstrated no effect of quetiapine or rivastigmine on improving clinically significant agitation and an increased cognitive decline associated with the use of quetiapine [4]. Finally, a small double-blind, placebo-controlled, randomized study has shown no significant difference between quetiapine and placebo in terms of efficacy on controlling agitation and psychosis among patients with dementia and parkinsonism [53]. In this study quetiapine was well tolerated and did not worse parkinsonism. As pointed out by the authors of this study, lack of power and a large placebo effect may have contributed to the resulted lack of efficacy.

A single double blind, randomized, placebo-controlled clinical trial has investigated the efficacy and safety of aripiprazole in patients with Alzheimer's disease and psychosis [21]. According to this 10-week study, aripiprazole at a mean dose of $10 \mathrm{mg}$ per day appeared to confer no benefit over placebo for controlling delusions and hallucinations and it was well tolerated.

Very recently, the results of a large effectiveness trial, the CATIE-AD (Clinical Antipsychotic Trials of Intervention Effectiveness-Alzheimer's Disease), have been published. According to this multicenter, double-blind, placebo-controlled trial on outpatients with Alzheimer's disease and psychosis, aggression or agitation, the effect of olanzapine (mean dose $5.5 \mathrm{mg}$ per day) and risperidone (mean dose 1.0 $\mathrm{mg}$ per day) in treating neuropsychiatric symptoms was equally beneficial and superior to the effect of placebo and quetiapine (mean dose $56.5 \mathrm{mg}$ per day) [76]. However, these benefits were evident only among those patients who tolerated these medications and did not discontinue them due to side effects. Similar rates of treatment discontinuation were reported in the different study groups. However, patients on antipsychotics discontinued mostly because of adverse effects while patients on placebo discontinued mostly because of lack of efficacy. According to authors' conclu- 
Table 1. Published Randomized Clinical Trials of Atypical Antipsychotics among Patients with BPSD

\begin{tabular}{|c|c|c|c|c|c|c|}
\hline Trial & Intervention & Daily Dose & Population & Setting & $\begin{array}{c}\text { Duration } \\
\text { (Weeks) }\end{array}$ & $\begin{array}{c}\text { Primary Efficacy } \\
\text { Measure }\end{array}$ \\
\hline Katz, 1999 [52] & risperidone $v s$ placebo & Fixed, $0.5,1.0$ or $2.0 \mathrm{mg}$ & $\begin{array}{c}\mathrm{N}=625 ; \\
\mathrm{AD}, \mathrm{VaD}, \text { mixed }\end{array}$ & $\begin{array}{l}\text { Nursing } \\
\text { home }\end{array}$ & 12 & BEHAVE-AD \\
\hline $\begin{array}{c}\text { De Deyn } 1999 \\
{[23]}\end{array}$ & $\begin{array}{l}\text { risperidone } v s \text { haloperidol } \\
\qquad v s \text { placebo }\end{array}$ & $\begin{array}{c}\text { Flexible, mean risperidone } \\
1.1 \mathrm{mg} \text {, mean haloperidol } \\
1.2 \mathrm{mg}\end{array}$ & $\begin{array}{c}\mathrm{N}=344 ; \\
\mathrm{AD}, \mathrm{VaD}, \text { mixed }\end{array}$ & $\begin{array}{l}\text { Nursing } \\
\text { home }\end{array}$ & 13 & $\begin{array}{l}\text { BEHAVE-AD, } \\
\text { CMAI, CGI }\end{array}$ \\
\hline $\begin{array}{c}\text { Brodaty, } 2003 \\
{[13]}\end{array}$ & risperidone $v s$ placebo & Flexible, mean $0.95 \mathrm{mg}$ & $\begin{array}{c}\mathrm{N}=309 ; \\
\mathrm{AD}, \mathrm{VaD}, \text { mixed }\end{array}$ & $\begin{array}{l}\text { Nursing } \\
\text { home }\end{array}$ & 12 & $\begin{array}{c}\text { CMAI, BEHAVE- } \\
\text { AD, CGI }\end{array}$ \\
\hline Street, 2000 [80] & olanzapine $v s$ placebo & Fixed, $5.0,10.0$ or $15.0 \mathrm{mg}$ & $\mathrm{N}=206 ; \mathrm{AD}$ & $\begin{array}{l}\text { Nursing } \\
\text { home }\end{array}$ & 6 & NPI-NH \\
\hline $\begin{array}{c}\text { De Deyn, } 2004 \\
{[22]}\end{array}$ & olanzapine $v s$ placebo & $\begin{array}{c}\text { Fixed, } 1.0,2.5,5.0 \text { or } 7.5 \\
\mathrm{mg}\end{array}$ & $\mathrm{N}=652 ; \mathrm{AD}$ & $\begin{array}{l}\text { Nursing } \\
\text { home }\end{array}$ & 10 & NPI-NH \\
\hline $\begin{array}{c}\text { Deberdt, } 2005 \\
{[24]}\end{array}$ & $\begin{array}{c}\text { olanzapine } v s \text { placebo } v s \\
\text { risperidone }\end{array}$ & $\begin{array}{c}\text { Flexible, mean olanzapine } \\
5.2 \mathrm{mg} \text {, mean risperidone } \\
1.0 \mathrm{mg}\end{array}$ & $\begin{array}{l}\mathrm{N}=298 ; \mathrm{AD}, \mathrm{VaD} \\
\text { mixed }\end{array}$ & $\begin{array}{l}\text { Outpatient } \\
\text { and residen- } \\
\text { tial }\end{array}$ & 10 & NPI, CGI \\
\hline $\begin{array}{c}\text { Ballard, } 2005 \\
{[4]}\end{array}$ & $\begin{array}{c}\text { quetiapine } v s \text { rivastigmine } \\
v s \text { placebo }\end{array}$ & $\begin{array}{l}\text { Flexible, range quetiapine } \\
\qquad 50-100 \mathrm{mg}\end{array}$ & $\mathrm{N}=93 ; \mathrm{AD}$ & $\begin{array}{l}\text { Nursing } \\
\text { home }\end{array}$ & 26 & CMAI,SIB \\
\hline $\begin{array}{c}\text { De Deyn, } 2005 \\
{[21]}\end{array}$ & aripiprazole $v s$ placebo & Fixed, 5,10 or $15 \mathrm{mg}$ & $\mathrm{N}=208 ; \mathrm{AD}$ & Outpatient & 10 & NPI, BPRS \\
\hline $\begin{array}{c}\text { Schneider, } 2006 \\
{[76]}\end{array}$ & $\begin{array}{l}\text { olanzapine } v s \text { quetiapine } \\
v s \text { risperidone } v s \text { placebo }\end{array}$ & $\begin{array}{c}\text { Flexible, mean olanzapine } \\
5.5 \mathrm{mg} \text {, mean quetiapine } \\
56.5 \mathrm{mg} \text {, mean risperidone } \\
1.0 \mathrm{mg})\end{array}$ & $\mathrm{N}=421 ; \mathrm{AD}$ & Outpatient & 36 & $\begin{array}{l}\text { Time from initial } \\
\text { treatment to dis- } \\
\text { continuation/ } \\
\text { CGIC }\end{array}$ \\
\hline $\begin{array}{c}\text { Zhong, } 2007 \\
{[90]}\end{array}$ & quetiapine $v s$. placebo & Fixed, 100 or $200 \mathrm{mg}$ & $\mathrm{N}=333 ; \mathrm{AD}$ & $\begin{array}{l}\text { Nursing } \\
\text { home }\end{array}$ & 10 & $\begin{array}{c}\text { PANSS-EC, CGI, } \\
\text { NPI-NH, CMAI }\end{array}$ \\
\hline $\begin{array}{c}\text { Kurlan, } 2007 \\
{[53]}\end{array}$ & quetiapine $v s$. placebo & Flexible, mean $120 \mathrm{mg}$ & $\begin{array}{c}\mathrm{N}=40 ; \mathrm{DLB}, \mathrm{PD}, \\
\mathrm{AD}\end{array}$ & Outpatient & 10 & BPRS \\
\hline
\end{tabular}

Abbreviations: $\mathrm{AD}=$ Alzheimer's disease; $\mathrm{VaD}=$ Vascular dementia; $\mathrm{DLB}=$ Dementia with Lewy Bodies; $\mathrm{PD}=\mathrm{Parkinson}$ disease with dementia; $\mathrm{BEHAVE}-\mathrm{AD}=\mathrm{Behavioral}$ Pathology in Alzheimer's disease rating scale; $\mathrm{CMAI}=$ Cohen-Mansfield Agitation Inventory; CGI=Clinical Global Impression; NPI= Neuropsychiatric Inventory; NPI$\mathrm{NH}=$ Neuropsychiatric Inventory -nursing home version; $\mathrm{SIB}=$ severe impairment battery; BPRS= Brief Psychiatric Rating Scale; CGIC=Clinical Global Impression of Change; PANSS-EC $=$ positive and negative syndrome scale-excitement component.

sions potential side effect associated with antipsychotic medications in dementia may outweigh possible benefits.

A comprehensive review of the available randomized, double blind, placebo-controlled trials has been conducted by Ballard and White for the Cochrane collaboration to determine the effectiveness of atypical antipsychotics for the treatment of psychiatric and behavioural symptoms in Alzheimer's disease [5]. The authors analyzed sixteen placebocontrolled trials among which only six studies were published in full in peer reviewed journals. According to the Cochrane authors, evidence suggests that both risperidone and olanzapine may reduce aggression and risperidone may also reduce psychosis compared to placebo. However, an increased risk of extrapyramidal symptoms and adverse cerebrovascular events associated with atypical antipsychotics would outweigh the modest effectiveness of these medications. According to Cochrane findings, due to the increased risk of adverse effects, the use of atypical antipsy- chotics in clinical practice would not be suitable and should be limited to those patients presenting with significant distress and risk associated with symptoms.

\section{SAFETY OF ANTIPSYCHOTICS}

At the time of their introduction in clinical practice, atypical antipsychotics have been reported to be characterized by a better safety profile compared to conventional medications, especially with respect to extrapyramidal symptoms such as parkinsonism and tardive diskinesia. Data from clinical trials substantially confirm the superior EPS profile of atypical over conventional antipsychotics [13, 22, 23, 52, 80]. Risperidone at dose of $1 \mathrm{mg}$ per day has been proven to cause less EPS compared with placebo and haloperidol [13, $23,52]$. However, this relative benefit of risperidone relative to haloperidol disappeared at dosages of $2 \mathrm{mg}$ per day or higher [52]. In two randomized trials of olanzapine there was no increased incidence of EPS in the olanzapine groups (at 
doses of 5 to $15 \mathrm{mg}$ per day) compared with the placebo group. Observational data supported findings from clinical trials $[22,80]$. Overall, the available evidence suggests that in dementia patients EPS are less frequently associated with atypical antipsychotics relative to conventional agents. However, parkinsonism and tardive diskinesia may be caused by atypical antipsychotics, especially at high dosages.

Beginning in 2002, warnings about a possible increased risk of cerebrovascular events (CVEs) and death among patients with dementia being treated with risperidone or olanzapine have been issued by drugs' manufacturers and health regulatory agencies worldwide [31, 41, 87, 88]. These concerns arose from the revision of both published and unpublished clinical trials on atypical antipsychotics among patients with dementia. According to the results of these analyses, risperidone was associated with a nearly 3 -fold increase in the risk of CVEs in dementia patients [41]. The risk associated with risperidone did not differ from the risk associated with placebo when serious CVEs including death, life threatening or leading to permanent disability events were considered. Also, a nearly 2-fold increase in the risk of CVEs associated with olanzapine was calculated but this estimate did not reach statistical significance [41]. More recently, a metaanalysis of 15 randomized clinical trials on patients with dementia being treated with atypical antipsychotics reported a $65 \%$ increased all cause mortality associated with atypical antipsychotics compared with placebo [74]. In spite of this growing evidence from clinical trials, data from several large observational studies failed to support the conclusion of a possible increased risk of CVEs and death associated with atypical antipsychotics $[36,42,57]$. Moreover, a recent large retrospective cohort study suggested that conventional antipsychotics may indeed carry a nearly $40 \%$ excess risk of death compared with atypical agents and therefore they would not represent a valid alternative to atypical compounds for the treatment of BPSD [86]. According to the available evidence, in April 2005, the FDA has issued a public health advisory to warn about a possible increased risk of death associated with atypical antipsychotics [31]. The FDA has asked manufacturers of these drugs to include a boxed warning in their labeling describing the risk and has reminded that atypical antipsychotics have not been approved for dementia which represents an off-label indication. The FDA has also anticipated a possible future extension of this warning to conventional antipsychotics.

Treatment with atypical antipsychotics among patients with dementia has been linked to some risk of lengthening of QTc interval at EKG [40, 78]. However, data available have suggested that atypical antipsychotics may not increase the risk of clinical outcomes related to QTc prolongation, including ventricular arrhythmias and sudden death and with respect to cardiac toxicity they may be safer than conventional medications $[57,71]$.

Atypical antipsychotics are known to cause a spectrum of metabolic adverse effects such as diabetes, hyperlipidaemia and weight gain among young and adult patients with schizophrenia [66]. In particular, the risk of weight gain, diabetes and hyperlipidaemia has been reported high for clozapine and olanzapine, moderately high for quetiapine and low for risperidone. To date, there is little evidence that patients with dementia being treated with atypical antipsychotics may experience such metabolic effects $[13,22,23,52$, $80]$. Also no data are available to investigate the extent to which such metabolic disturbances may contribute to the possible cardiovascular toxicity associated with atypical antipsychotics.

\section{CONCLUSIONS}

BPSD represent one of the main mental issues in the geriatric population. To date, limited evidence supports available therapeutic strategies and current recommendations mainly derive from consensus of experts $[1,7,27]$. Based on safety considerations and in light of the high rates of placebo-response in clinical trials, non pharmacological approaches are generally recognized as the first-line strategy for the treatment of BPSD. The pharmacological approach based on the use of antipsychotic medications is recommended for the short-term treatment (up to three months) and among those patients who manifest severe symptoms that may cause extreme distress and harm to patients or others. Antipsychotic prescription is limited and strictly regulated in many countries and BPSD are still an off-label indication for most of these agents.

In clinical practice, the therapeutic choice between atypical and conventional medications should be based on a careful evaluation of the potential benefits and risks of both classes of antipsychotics as well as patients' individual risk profile. Physicians should evaluate each patient individually and judge whether or not the magnitude of the potential risks outweighs the benefits that can be expected from the use of antipsychotics.

Finally, evidence for potential pharmacological alternatives to antipsychotics is also lacking. In the near future, research efforts should be directed to investigate and identify alternative therapeutic strategies which may combine non pharmacological treatments with drug therapy and need to be tailored to patients with dementia and their families.

\section{REFERENCES}

[1] Alexopoulos, G.S., Jeste, D.V., Chung, H., Carpenter, D., Ross, R., Docherty, J.P. (2005) The expert consensus guideline series. Treatment of dementia and its behavioral disturbances. Introduction: methods, commentary, and summary. Postgrad. Med., Spec No, 6-22.

[2] American Geriatrics Society and American Association for Geriatric Psychiatry. (2003) Consensus statement on improving the quality of mental health care in US nursing homes: management of depression and behavioral symptoms associated with dementia. $J$. Am. Geriatr. Soc., 51, 1287-1298.

[3] Baldessarini, R.J., Frankenburg, F.R. (1991) Clozapine. A novel antipsychotic agent. N. Engl. J. Med., 324, 746-754.

[4] Ballard, C., Margallo-Lana, M., Juszczak, E., Douglas, S., Swann, A., Thomas, A., O'Brien, J., Everratt, A., Sadler, S., Maddison, C., Lee, L., Bannister, C., Elvish, R., Jacoby, R. (2005) Quetiapine and rivastigmine and cognitive decline in Alzheimer's disease: randomised double blind placebo controlled trial. $B M J, 330,874$.

[5] Ballard, C., Waite, J. (2006) The effectiveness of atypical antipsychotics for the treatment of aggression and psychosis in Alzheimer's disease. Cochrane Database Syst. Rev., 1, CD003476.

[6] Barnes, R., Veith, R., Okimoto, J., Raskind, M., Gumbrecht, G. (1982) Efficacy of antipsychotic medications in behaviorally disturbed dementia patients. Am. J. Psychiatry, 139, 1170-1174.

[7] Benoit, M., Arbus, C., Blanchard, F., Camus, V., Cerase, V., Clement, J.P., Fremont, P., Guerin, O., Hazif, T.C., Jeanblanc, F., La- 
font, C., Moreaud, O., Pedra, M., Poncet, M., Richard, H.S., Rigaud, A.S., Sotto, M.M.E., Touchon, J., Vellas, B., Fitten, L.J., Robert, P.H. (2006) Professional consensus on the treatment of agitation, aggressive behaviour, oppositional behaviour and psychotic disturbances in dementia. J. Nutr. Health Aging, 10, 410-415.

[8] Benoit, M., Brocker, P., Clement, J.P., Cnockaert, X., Hinault, P., Nourashemi, F., Pancrazi, M.P., Portet, F., Robert, P., Thomas, P., Verny, M., Groupe de consensus Théma. (2005) Behavioral and psychological symptoms in dementia: description and management. Rev. Neurol (Paris), 161, 357-366.

[9] Benoit, M., Robert, P.H., Staccini, P., Brocker, P., Guerin, O., Lechowski, L., Vellas, B., REAL FR Group. (2005) One-year longitudinal evaluation of neuropsychiatric symptoms in Alzheimer's disease. The REAL.FR Study. J. Nutr. Health Aging, 9, 95-99.

[10] Benoit, M., Staccini, P., Brocker, P., Benhamidat, T., Bertogliati, C., Lechowski, L., Tortrat, D., Robert, P.H. (2003) Behavioral and psychologic symptoms in Alzheimer's disease: results of the REAL.FR study. Rev. Med. Int., 24, 319s-324s.

[11] Bozeat, S., Gregory, C.A., Ralph, M.A., Hodges, J.R. (2000) Which neuropsychiatric and behavioural features distinguish frontal and temporal variants of frontotemporal dementia from Alzheimer's disease? J. Neurol. Neurosurg. Psychiatry, 69, 178-186.

[12] Braak, H., Braak, E. (1991) Neuropathological stageing of Alzheimer-related changes. Acta Neuropathol., V82, 239-259.

[13] Brodaty, H., Ames, D., Snowdon, J., Woodward, M., Kirwan, J., Clarnette, R., Lee, E., Lyons, B., Grossman, F. (2003) A randomized placebo-controlled trial of risperidone for the treatment of aggression, agitation, and psychosis of dementia. J. Clin. Psychiatry, 64, 134-143.

[14] Buhr, G.T., White, H.K. (2006) Difficult behaviors in long-term care patients with dementia. J. Am. Med. Dir. Assoc., 7, 180-192.

[15] Burris, K.D., Molski, T.F., Xu, C., Ryan, E., Tottori, K., Kikuchi, T., Yocca, F.D., Molinoff, P.B. (2002) Aripiprazole, a Novel Antipsychotic, Is a High-Affinity Partial Agonist at Human Dopamine D2 Receptors. J. Pharmacol. Exp. Ther., 302, 381-389.

[16] Chan, D.C., Kasper, J.D., Black, B.S., Rabins, P.V. (2003) Prevalence and correlates of behavioral and psychiatric symptoms in community-dwelling elders with dementia or mild cognitive impairment: the Memory and Medical Care Study. Int. J. Geriatr. Psychiatry, 18, 174-182.

[17] Cohen, C.A., Gold, D.P., Shulman, K.I., Wortley, J.T., McDonald, G., Wargon, M. (1993) Factors determining the decision to institutionalize dementing individuals: a prospective study. Gerontologist, 33, 714-720.

[18] Cohen-Mansfield, J., Billig, N. (1998) Agitated behaviours in the elderly. I: a conceptual review. J. Am. Geriatr. Soc., 36, 7-12.

[19] Collaborative Working Group on Clinical Trial Evaluations. (1998) Treatment of special populations with the atypical antipsychotics. J. Clin. Psychiatr., 59(suppl 12), 46-52.

[20] Cummings, J.L., Diaz, C., Levy, M. (1996) Behavioral syndromes in neurodegenerative diseases: frequency and significance. Semin. Neuropsychiatry, 1, 241-247.

[21] De Deyn, P., Jeste, D.V., Swanink, R., Kostic, D., Breder, C., Carson, W.H., Iwamoto, T. (2005) Aripiprazole for the treatment of psychosis in patients with Alzheimer's disease: a randomized, placebo-controlled study. J. Clin. Psychopharmacol., 25, 463-467.

[22] De Deyn, P.P., Carrasco, M.M., Deberdt, W., Jeandel, C., Hay, D.P., Feldman, P.D., Young, C.A., Lehman, D.L., Breier, A. (2004) Olanzapine versus placebo in the treatment of psychosis with or without associated behavioral disturbances in patients with Alzheimer's disease. Int. J. Geriatr. Psychiatry, 19, 115-126.

[23] De Deyn, P.P., Rabheru, K., Rasmussen, A., Bocksberger, J.P., Dautzenberg, P.L., Eriksson, S., Lawlor, B.A. (1999) A randomized trial of risperidone, placebo, and haloperidol for behavioral symptoms of dementia. Neurology, 53, 946-955.

[24] Deberdt, W.G., Dysken, M.W., Rappaport, S.A., Feldman, P.D., Young, C.A., Hay, D.P., Lehman, D.L., Dossenbach, M., Degenhardt, E.K., Breier, A. (2005) Comparison of olanzapine and risperidone in the treatment of psychosis and associated behavioral disturbances in patients with dementia. Am. J. Geriatr. Psychiatry, 13, 722-730.

[25] Eustace, A., Coen, R., Walsh, C., Cunningham, C.J., Walsh, J.B., Coakley, D., Lawlor, B.A. (2002) A longitudinal evaluation of behavioural and psychological symptoms of probable Alzheimer's disease. Int. J. Geriatr. Psychiatry, 17, 968-973.

[26] Eustace, A., Kidd, N., Greene, E., Fallon, C., Bhrain, S.N., Cunningham, C., Coen, R., Walsh, J.B., Coakley, D., Lawlor, B.A.
(2001) Verbal aggression in Alzheimer's disease. Clinical, functional and neuropsychological correlates. Int. J. Geriatr. Psychiatry, 16, 858-861.

[27] Expert Consensus Panel for Dementia. (2005) The expert consensus guideline series. Treatment of dementia and its behavioral disturbances. Postgrad. Med., Spec No, 1-111.

[28] Factor, S.A. (2002) Pharmacology of atypical antipsychotics. Clin. Neuropharmacol., 25, 153-157.

[29] Farber, N.B., Rubin, E.H., Newcomer, J.W., Kinscherf, D.A., Miller, J.P., Morris, J.C., Olney, J.W., McKeel, D.W. Jr. (2000) Increased neocortical neurofibrillary tangle density in subjects with alzheimer disease and psychosis. Arch. Gen. Psychiatry, 57, 1165-1173.

[30] Farde, L., Nordstrom, A.L., Wiesel, F.A., Pauli, S., Halldin, C., Sedvall, G. (1992) Positron emission tomographic analysis of central D1 and D2 dopamine receptor occupancy in patients treated with classical neuroleptics and clozapine. Relation to extrapyramidal side effects. Arch. Gen. Psychiatry, 49, 538-544.

[31] FDA Public Health Advisory. (2005) Deaths with Antipsychotics in Elderly Patients with Behavioral Disturbances. Available at http://www.fda.gov/cder/drug/advisory/antipsychotics.htm (accessed April 11, 2005).

[32] Fischman, A.J., Bonab, A.A., Babich, J.W., Alpert, N.M., Rauch, S.L., Elmaleh, D.R., Shoup, T.M., Williams, S.A., Rubin, R.H. (1996) Positron emission tomographic analysis of central 5hydroxytryptamine 2 receptor occupancy in healthy volunteers treated with the novel antipsychotic agent, ziprasidone. J. Pharmacol. Exp. Ther., 279, 939-947.

[33] Fitten, L.J. (2006) Management of behavioral and psychiatric symptoms of dementia. J. Nutr. Health Aging, 10, 409.

[34] Forstl, H., Burns, A., Levy, R., Cairns, N. (1994) Neuropathological correlates of psychotic phenomena in confirmed Alzheimer's disease. Br. J. Psychiatry, 165, 53-59.

[35] Gerlach, J. (2000) Atypical antipsychotics: an inspiring but confusing concept. Psychopharmacology, 148, 1-2.

[36] Gill, S.S., Rochon, P.A., Herrmann, N., Lee, P.E., Sykora, K., Gunraj, N., Normand, S.L., Gurwitz, J.H., Marras, C., Wodchis, W.P., Mamdani, M. (2005) Atypical antipsychotic drugs and risk of ischaemic stroke: population based retrospective cohort study. BMJ, 330, 445.

[37] Glick, I.D., Murray, S.R., Vasudevan, P., Marder, S.R., Hu, R.J. (2001) Treatment with atypical antipsychotics: new indications and new populations. J. Psychiatr. Res., 35, 187-191.

[38] Harding, A.J., Broe, G.A., Halliday, G.M. (2002) Visual hallucinations in Lewy body disease relate to Lewy bodies in the temporal lobe. Brain, 125, 391-403.

[39] Harvey, R.J., Ellison, D., Hardy, J., Hutton, M., Roques, P.K., Collinge, J., Fox, N.C., Rossor, M.N. (1998) Chromosome 14 familial Alzheimer's disease: the clinical and neuropathological characteristics of a family with a leucine-serine (L250S) substitution at codon 250 of the presenilin 1ágene. J. Neurol. Neurosurg. Psychiatry, 64, 44-49.

[40] Hennessy, S., Bilker, W.B., Knauss, J.S., Margolis, D.J., Kimmel, S.E., Reynolds, R.F., Glasser, D.B., Morrison, M.F., Strom, B.L. (2002) Cardiac arrest and ventricular arrhythmia in patients taking antipsychotic drugs: cohort study using administrative data. BMJ, 325, 1070-1074

[41] Herrmann, N., Lanctot, K.L. (2005) Do atypical antipsychotics cause stroke? CNS Drugs, 19, 91-103.

[42] Herrmann, N., Mamdani, M., Lanctot, K.L. (2004) Atypical antipsychotics and risk of cerebrovascular accidents. Am. J. Psychiatry, 161, 1113-1115.

[43] Hirono, N., Mega, M.S., Dinov, I.D., Mishkin, F., Cummings, J.L. (2000) Left frontotemporal hypoperfusion is associated with aggression in patients with dementia. Arch. Neurol., 57, 861-866.

[44] Holmes, C., Arranz, M.J., Powell, J.F., Collier, D.A., Lovestone, S. (1998) 5-HT2A and 5-HT2C receptor polymorphisms and psychopathology in late onset Alzheimer's disease. Hum. Mol. Genet., 7, 15071509 .

[45] Holtzer, R., Tang, M.X., Devanand, D.P., Albert, S.M., Wegesin, D.J., Marder, K., Bell, K., Albert, M., Brandt, J., Stern, Y. (2003) Psychopathological features in Alzheimer's disease: course and relationship with cognitive status. J. Am. Geriatr. Soc., 51, 953-960.

[46] Jibson, M.D., Tandon, R. (1998) New atypical antipsychotic medications. J. Psychiat. Res., 32, 215-228.

[47] Jost, B.C., Grossberg, G.T. (1996) The evolution of psychiatric symptoms in Alzheimer's disease: a natural history study. J. Am. Geriatr. Soc., 44, 1078-1081. 
[48] Kapur, S., Remington, G., Zipursky, R.B., Wilson, A.A., Houle, S. (1995) The D2 dopamine receptor occupancy of risperidone and its relationship to extrapyramidal symptoms: a PET study. Life Sci., 57, L103-L107.

[49] Kapur, S., Seeman, P. (2001) Does fast dissociation from the dopamine D2 receptor explain the action of atypical antipsychotics?: A new hypothesis. Am. J. Psychiatry, 158, 360-369.

[50] Kapur, S., Zipursky, R., Jones, C., Remington, G., Houle, S. (2000) Relationship between dopamine D2 occupancy, clinical response, and side effects: A double-blind pet study of first-episode schizophrenia. Am. J. Psychiatry, 157, 514-520.

[51] Kapur, S., Zipursky, R.B., Remington, G. (1999) Clinical and theoretical implications of 5-HT2 and D2 receptor occupancy of clozapine, risperidone, and olanzapine in schizophrenia. Am. J. Psychiatry, 156, 286-293.

[52] Katz, I.R., Jeste, D.V., Mintzer, J.E., Clyde, C., Napolitano, J., Brecher, M. (1999) Comparison of risperidone and placebo for psychosis and behavioral disturbances associated with dementia: a randomized, double-blind trial. Risperidone Study Group. J. Clin. Psychiatry, 60, 107-115.

[53] Kurlan, R., Cummings, J., Raman, R., Thal, L., for the Alzheimer's Disease Cooperative Study Group. (2007) Quetiapine for agitation or psychosis in patients with dementia and parkinsonism. Neurology, 68, 1356-1363.

[54] Levy, M.L., Cummings, J.L., Fairbanks, L.A., Bravi, D., Calvani, M., Carta, A. (1996) Longitudinal assessment of symptoms of depression, agitation, and psychosis in 181 patients with Alzheimer's disease. Am. J. Psychiatry, 153, 1438-1443.

[55] Levy, M.L., Miller, B.L., Cummings, J.L., Fairbanks, L.A., Craig, A. (1996) Alzheimer disease and frontotemporal dementias. Behavioral distinctions. Arch. Neurol., 53, 687-690.

[56] Lidsky, T.I., Yablonsky-Alter, E., Zuck, L., Banerjee, S.P. (1993) Anti-glutamatergic effects of clozapine. Neurosci. Lett., 163, 155-158.

[57] Liperoti, R., Gambassi, G., Lapane, K.L., Chiang, C., Pedone, C., Mor, V., Bernabei, R. (2005) Cerebrovascular events among elderly nursing home patients treated with conventional or atypical antipsychotics. J. Clin. Psychiatry, 66, 1090-1096.

[58] Liperoti, R., Gambassi, G., Lapane, K.L., Chiang, C., Pedone, C., Mor, V., Bernabei, R. (2005) Conventional and atypical antipsychotics and the risk of hospitalization for ventricular arrhythmias or cardiac arrest. Arch. Int. Med., 165, 696-701.

[59] Liperoti, R., Mor, V., Lapane, K.L., Pedone, C., Gambassi, G., Bernabei, R. (2003) The use of atypical antipsychotics in nursing home. J. Clin. Psychiatry, 64, 1106-1112.

[60] Lonergan, E., Luxenberg, J., Colford, J. (2002) Haloperidol for agitation in dementia. Cochrane Database Syst. Rev., 2, CD002852.

[61] Lopez, O.L., Smith, G., Becker, J.T., Meltzer, C.C., DeKosky, S.T. (2001) The psychotic phenomenon in probable Alzheimer's disease: a positron emission tomography study. J. Neuropsychiat. Clin. Neurosci., 13, 50-55.

[62] Lyketsos, C.G., Lopez, O., Jones, B., Fitzpatrick, A.L., Breitner, J., DeKosky, S. (2002) Prevalence of neuropsychiatric symptoms in dementia and mild cognitive impairment: results from the cardiovascular health study. JAMA, 288, 1475-1483.

[63] Lyketsos, C.G., Steinberg, M., Tschanz, J.T., Norton, M.C., Steffens, D.C., Breitner, J.C. (2000) Mental and behavioral disturbances in dementia: findings from the Cache County Study on Memory in Aging. Am. J. Psychiatry, 157, 708-714.

[64] McKeith, I., Cummings, J. (2005) Behavioural changes and psychological symptoms in dementia disorders. Lancet Neurol., 4, 735-742.

[65] Meins, W., Frey, A., Thiesemann, R. (1998) Premorbid personality traits in Alzheimer's disease: do they predispose to noncognitive behavioral symptoms? Int. Psychogeriatr., 10, 369-378.

[66] Melkersson, K., Dahl, M.L. (2004) Adverse metabolic effects associated with atypical antipsychotics: literature review and clinical implications. Drugs, 64, 701-723.

[67] Meltzer, H.Y., Matsubara, S., Lee, J.C. (1989) Classification of typical and atypical antipsychotic drugs on the basis of dopamine D-1, D-2 and serotonin 2 pKi values. J. Pharmacol. Exp. Ther., 251, 238-246.

[68] Mossman, D., Lehrer, D.S. (2000) Conventional and atypical antipsychotics and the evolving standard of care. Psychiatr. Serv., 51, 1528-1535.

[69] Neary, D., Snowden, J.S., Gustafson, L., Passant, U., Stuss, D., Black, S., Freedman, M., Kertesz, A., Robert, P.H., Albert, M., Boone, K., Miller, B.L., Cummings, J., Benson, D.F. (1998) Fron- totemporal lobar degeneration: a consensus on clinical diagnostic criteria. Neurology, 51, 1546-1554.

[70] Nordström, A.L., Farde, L., Wiesel, F.A., Forslund, K., Pauli, S., Halldin, C., Uppfeldt, G. (1993) Central D2-dopamine receptor occupancy in relation to antipsychotic drug effects: A double-blind PET study of schizophrenic patients. Biol. Psychiatr., 33, 227-235.

[71] Ray, W.A., Meredith, S., Thapa, P.B., Meador, K.G., Hall, K., Murray, K.T. (2001) Antipsychotics and the risk of sudden cardiac death. Arch. Gen. Psychiatry, 58, 1161-1167.

[72] Richelson, E. (1996) Preclinical pharmacology of neuroleptics: focus on new generation compounds. J. Clin. Psychiatry, 57(Suppl. 11), 411 .

[73] Scarmeas, N., Brandt, J., Albert, M., Hadjigeorgiou, G., Papadimitriou, A., Dubois, B., Sarazin, M., Devanand, D., Honig, L., Marder, K., Bell, K., Wegesin, D., Blacker, D., Stern, Y. (2005) Delusions and hallucinations are associated with worse outcome in Alzheimer disease. Arch. Neurol., 62, 1601-1608.

[74] Schneider, L.S., Dagerman, K.S., Insel, P. (2005) Risk of death with atypical antipsychotic drug treatment for dementia: metaanalysis of randomized placebo-controlled trials. JAMA, 294, 19341943.

[75] Schneider, L.S., Pollock, V.E., Lyness, S.A. (1990) A metaanalysis of controlled trials of neuroleptic treatment in dementia. J. Am. Geriatr. Soc., 38, 553-563.

[76] Schneider, L.S., Tariot, P.N., Dagerman, K.S., Davis, S.M., Hsiao, J.K., Ismail, M.S., Lebowitz, B.D., Lyketsos, C.G., Ryan, J.M., Stroup, T.S., Sultzer, D.L., Weintraub, D., Lieberman, J.A. CATIEAD Study Group. (2006) Effectiveness of atypical antipsychotic drugs in patients with Alzheimer's disease. N. Engl. J. Med., 355, 1525-1538.

[77] Schoemaker, H., Claustre, Y., Fage, D., Rouquier, L., Chergui, K., Curet, O., Oblin, A., Gonon, F., Carter, C., Benavides, J., Scatton, B. (1997) Neurochemical Characteristics of Amisulpride, an Atypical Dopamine D2/D3 Receptor Antagonist with Both Presynaptic and Limbic Selectivity. J. Pharmacol. Exp. Ther., 280, 83-97.

[78] Straus, S.M., Bleumink, G.S., Dieleman, J.P., van der Lei, J., 't Jong, G.W., Kingma, J.H., Sturkenboom, M.C., Stricker, B.H. (2004) Antipsychotics and the risk of sudden cardiac death. Arch. Int. Med., 164, 1293-1297.

[79] Strauss, M.E., Lee, M.M., DiFilippo, J.M. (1997) Premorbid personality and behavioral symptoms in Alzheimer disease. Some cautions. Arch. Neurol., 54, 257-259.

[80] Street, J.S., Clark, W.S., Gannon, K.S., Cummings, J.L., Bymaster, F.P., Tamura, R.N., Mitan, S.J., Kadam, D.L., Sanger, T.M., Feldman, P.D., Tollefson, G.D., Breier, A. (2000) Olanzapine treatment of psychotic and behavioral symptoms in patients with Alzheimer disease in nursing care facilities: a double-blind, randomized, placebo-controlled trial. The HGEU Study Group. Arch. Gen. Psychiatry, 57, 968-976.

[81] Sukonick, D.L., Pollock, B.G., Sweet, R.A., Mulsant, B.H., Rosen, J., Klunk, W.E., Kastango, K.B., DeKosky, S.T., Ferrell, R.E. (2001) The 5-HTTPR*S/*L Polymorphism and Aggressive Behavior in Alzheimer Disease. Arch. Neurol., 58, 1425-1428.

[82] Sultzer, D.L., Brown, C.V., Mandelkern, M.A., Mahler, M.E., Mendez, M.F., Chen, S.T., Cummings, J.L. (2003) Delusional thoughts and regional frontal/temporal cortex metabolism in Alzheimer's disease. Am. J. Psychiatry, 160, 341-349.

[83] Sweet, R.A., Nimgaonkar, V.L., Kamboh, M.I., Lopez, O.L., Zhang, F., DeKosky, S.T. (1998) Dopamine Receptor Genetic Variation, Psychosis, and Aggression in Alzheimer Disease. Arch. Neurol., 55, 1335-1340.

[84] Sweet, R.A., Pollock, B.G., Sukonick, D.L., Mulsant, B.H., Rosen, J., Klunk, W.E., Kastango, K.B., DeKosky, S.T., Ferrell, R.E. (2001) The 5-HTTPR polymorphism confers liability to a combined phenotype of psychotic and aggressive behavior in Alzheimer disease. Int. J. Psychogeriatr., 13, 401-409.

[85] Tekin, S., Mega, M.S., Masterman, D.M., Chow, T., Garakian, J., Vinters, H.V., Cummings, J.L. (2001) Orbitofrontal and anterior cingulate cortex neurofibrillary tangle burden is associated with agitation in Alzheimer disease. Ann. Neurol., 49, 355-361.

[86] Wang, P.S., Schneeweiss, S., Avorn, J., Fischer, M.A., Mogun, H., Solomon, D.H., Brookhart, M.A. (2005) Risk of death in elderly users of conventional vs. atypical antipsychotic medications. $N$. Engl. J. Med., 353, 2335-2341. 
[87] Wooltorton, E. (2004) Olanzapine (Zyprexa): increased rate of cerebrovascular events in dementia trials. CMAJ, 170, 1395.

[88] Wooltorton, E. (2002) Risperidone (Risperdal): increased rate of cerebrovascular events in dementia trials. CMAJ, 167, 1269-1270.

[89] Xiberas, X., Martinot, J.L., Mallet, L., Artiges, E., Loc'H, C., Mazière, B., Paillère-Martinot, M.L. (2001) Extrastriatal and striatal D2 dopamine receptor blockade with haloperidol or new antipsychotic drugs in patients with schizophrenia. Br. J. Psychiatry, 179, 503508 .

[90] Zhong, K.X., Tariot, P.N., Mintzer, J., Minkwitz, M.C., Devine, N.A. (2007) Quetiapine to treat agitation in dementia: a randomized double-blind, placebo-controlled study. Curr. Alzheimer Res., 4, 81-93. 